\title{
QUEEN'S
UNIVERSITY
BELFAST
}

\section{Northern Ireland Representation at Westminster: Constitutional Conundrums and Political Manoeuvres}

Walker, G., \& Mulvenna, G. (2015). Northern Ireland Representation at Westminster: Constitutional Conundrums and Political Manoeuvres. Parliamentary History, 34(2), 237-255. https://doi.org/10.1111/1750-0206.12141

Published in:

Parliamentary History

Document Version:

Peer reviewed version

Queen's University Belfast - Research Portal:

Link to publication record in Queen's University Belfast Research Portal

Publisher rights

Copyright 2015 Wiley

This is the peer reviewed version of the following article: Walker, G. and Mulvenna, G. (2015), Northern Ireland Representation at Westminster: Constitutional Conundrums and Political Manœuvres. Parliamentary History, 34: 237-255., which has been published in final form at http://onlinelibrary.wiley.com/doi/10.1111/1750-0206.12141/abstract. This article may be used for non-commercial purposes in accordance With Wiley Terms and Conditions for self-archiving.

General rights

Copyright for the publications made accessible via the Queen's University Belfast Research Portal is retained by the author(s) and / or other copyright owners and it is a condition of accessing these publications that users recognise and abide by the legal requirements associated with these rights.

Take down policy

The Research Portal is Queen's institutional repository that provides access to Queen's research output. Every effort has been made to ensure that content in the Research Portal does not infringe any person's rights, or applicable UK laws. If you discover content in the Research Portal that you believe breaches copyright or violates any law, please contact openaccess@qub.ac.uk. 


\title{
Northern Ireland Representation at Westminster: Constitutional Conundrums and Political Manœuvres
}

\author{
GRAHAM WALKER and GARETH MULVENNA \\ Queen’s University Belfast
}

This article focuses on the issue of Northern Ireland's representation at Westminster. It investigates the political context of the decision to increase Northern Ireland's representation in the house of commons at Westminster from 12 members to 17 in 1978-9. Exploring this episode in more detail, it is argued, provides a more informed overall understanding of the history of devolution in the UK and of the way issues concerning Northern Ireland often overlapped with questions of constitutional change in Scotland and Wales. The article also throws light on the matter of Northern Ireland MPs and their voting rights at Westminster during Northern Ireland's experience of devolution prior to 1972.

Keywords: Northern Ireland; representation; Westminster parliament; devolution; Labour government; Ulster Unionism; integration; Kilbrandon Commission; Speaker's conference

\section{Introduction}

The main purpose of this article is to investigate the political context of the decision to increase Northern Ireland's representation in the house of commons at Westminster from 12 members to 17 in 1978-9. It will shed light on the way that issues concerning Northern Ireland following the suspension of the Stormont parliament in 1972 (and its dissolution in 1973), in particular efforts to bring peace, could coincide and overlap significantly with questions of constitutional change (devolution) for Scotland and Wales, and suggest that the 
UK's constitutional debates of this decade cannot be properly understood without the Northern Ireland dimension. In addition, the article will examine the political manœuvring around the issue of the increase in Northern Ireland MPs and its centrality to the working arrangement reached between the Callaghan Labour government and the Ulster Unionists from the spring of 1977 to the end of the government in 1979.

The article will first provide some background to the controversy of the Northern Ireland increase by discussing briefly the history of relations between the Stormont parliament and Westminster, and the way that the issue of representation - later to become known as the 'West Lothian Question' during the debates on devolution for Scotland and Wales - manifested itself when Northern Ireland, in the period between 1921 and 1972, was the sole part of the UK to experience devolution.

\section{An Uneasy Relationship: Interactions between Stormont and Westminster, 1921-72}

Between the birth in 1921 of Northern Ireland as a devolved unit of government and the turbulence of the 1960s, relations between Belfast and London were, for the most part, quietly harmonious. Between 1921 and 1940, when Prime Minister Lord Craigavon’s Unionist regime held power in Stormont, devolution was not used in order to diverge significantly from Britain - indeed Craigavon's governments attempted as much as possible to affirm the province's British identity through the constitutional arrangements that Unionists had been given. For example, a ‘step-by-step’ process was implemented in relation to social services as a means of minimising the disjunctive effects of devolution, namely the detachment of Northern Ireland politically from Westminster and the British party system. ${ }^{1}$ While those in power in Northern Ireland balanced the promotion of a unique Ulster identity with an obligation to ensure that their constituents were socially on a par with those on the mainland, members of parliament from Northern Ireland holding seats in the Westminster house of commons were able to vote on social and political matters which affected only those 
living in England, Scotland and Wales. For the 50-year period when Northern Ireland possessed devolution, the MPs returned to Westminster were overwhelmingly Unionists, and, except on rare occasions, chose to take the Conservative whip. These MPs, as Jackson points out, were not delegates of the Unionist government in Belfast, and relations between the two were often tense and problematic, especially following the Second World War. ${ }^{2}$

The anomaly of the Ulster MPs voting at Westminster on non-Ulster matters, rechristened ‘The West Lothian Question’ during debates on Scottish and Welsh devolution in the 1970s and the subject of the recent McKay Commission enquiry, ${ }^{3}$ generally went unchallenged until notable questions were raised over the manner in which this voting privilege was exercised during an episode that occurred during Harold Wilson's initial term as prime minister from 1964 to 1966.

Wilson possessed a visionary strategy for the modernisation of industry and technological advancement, and he was eager to lay down an early marker with the proposed nationalisation of the steel industry. This would not prove to be straightforward and the measure was predictably opposed by the Conservatives who drew on the support of Ulster Unionist MPs at Westminster in attempting to block Wilson's ambitions, despite the fact that the issue would not impact on Northern Ireland. Wilson was understandably vexed at this apparent anomaly. He had already witnessed two of his more right-wing back benchers, Woodrow Wyatt and Desmond Donnelly, oppose his steel plans, leading him initially to back down rather than jeopardise his thin majority. ${ }^{4}$ Frustrated by Unionists potentially setting up another obstacle to his ambitions, Wilson asked his attorney general, Elwyn Jones, to devise an 'in and out' solution to the seeming incongruity of Northern Irish MPs at Westminster assisting in the buffering of a proposed legislative process which was outside their constitutional area of concern. A similar 'in and out' solution had been proposed during the time of Gladstone's first Home Rule Bill of the late 19th century. The proposal then, which 
was eventually thought to be unworkable and dropped, would have allowed Irish MPs to vote on 'imperial' issues but not on those of domestic concern to Great Britain. ${ }^{5}$ Wilson perhaps anticipated - or more to the point, hoped - that Elwyn Jones would be able to design a modern version of this and thus prevent the Conservatives utilising the support of Ulster Unionist MPs at Westminster. Wilson, moreover, made direct contact on the matter with Northern Ireland's prime minster and Unionist Party leader, Terence O’Neill. O’Neill explained that there were far fewer MPs from Northern Ireland than population numbers warranted, and that this was the 'trade-off' that had hardened into a convention, or 'gentleman's agreement', best left undisturbed. ${ }^{6}$ This was a point that would be made regularly when the debate was joined in the 1970s over the question of revising the number of Northern Ireland representatives. Wilson, however, was undeterred and went so far as to suggest that O’Neill might advise the Unionist members in the house of commons not to vote on certain controversial subjects such as race relations. ${ }^{7}$ Away from these prickly exchanges between Wilson and O’Neill, Elwyn Jones duly investigated the possibility of implementing an 'in and out' solution but concluded that it was too complex an issue to resolve. Jones's difficulty foreshadowed what lay in store for those who later tried to formulate an answer to the conundrum.

The shadow attorney general, Peter Thorneycroft, rebuked Wilson's attempts to tamper with MPs' voting rights and protested on behalf of the Conservatives (and ultimately the Unionists), declaring in the house of commons in October 1965, that: 'every Member of the House of Commons is equal with every other Member of the House of Commons, and that all of us will speak on all subjects'. ${ }^{8}$ Notwithstanding Wilson's antipathy towards the Unionist MPs who sat in the house of commons from 1964 to 1966 and the complications they caused, British Steel was set up in July 1967 following Labour’s more emphatic election victory of 1966. However, this episode and Wilson's unsuccessful attempts to change 
parliamentary convention brought to bear the complexities of Northern Ireland's influence as a devolved part of the UK on matters at Westminster. During this period, the Northern Ireland prime minister, Terence O’Neill, was attempting to lower sectarian passions through the promotion of the benefits of regional planning, ${ }^{9}$ and although O’Neill's vision for growth was often somewhat cosmetic, he was an evangelist for the potential that devolution offered; indeed, he supported its extension to other parts of the UK. ${ }^{10}$ It would be during the late 1960s and 1970s when Northern Irish society was in a state of flux due to civil disorder and paramilitary violence, that more notice would be taken of Northern Ireland's system of government, its relationship with Westminster, and the possibilities of the province as a devolutionary model. In written evidence for the royal (Kilbrandon) commission on the constitution in 1972, G.B. Adams, a self-proclaimed 'Ulster Protestant of the Liberal Home Rule tradition', ${ }^{11}$ bemoaned the fact that the violence on the streets had undermined the system of government in Northern Ireland such as to suggest its abolition 'at a time when general trends of thought, which have called the Commission into being, would otherwise point not merely to its preservation but to an extension of its powers and functions'. ${ }^{12}$ The Northern Ireland parliament was, in fact, prorogued by the Conservative government in March 1972 in light of the deleterious security situation and worsening community relations.

Concurrent with Wilson's difficulties over the steel issue, a house of commons exchange on the subject of Northern Ireland in October 1965 highlighted the constitutional anomaly of the MPs' voting rights in some detail. Paul Rose, MP for Manchester Blackley and later to be chairman of the Campaign for Democracy in Ulster, took the opportunity of the constituency boundaries question in Northern Ireland being raised to challenge the Unionist MPs in the House, and Sir Knox Cunningham in particular, for the perceived ills wrought by Unionist hegemony and gerrymandering. ${ }^{13}$ As Rose's attack on Unionist rule in Northern Ireland intensified, the formalities and etiquette of the House were called into 
question, with the issue of MPs interfering in matters of other constituencies being

highlighted. Addressing this point, Captain Lawrence (Willy) Orr, Unionist MP for Down

South, stated:

There is one other matter in the hon. Member's speech to which I shall refer which is in a way extraneous to the debate but is not out of order. He queried whether it was right for Members of this House who come from Northern Ireland to take part in debating everything which comes before this House. In other words, he seemed to be suggesting that perhaps it was wrong for hon. Members from Northern Ireland to interfere in matters which were, let us say, purely English matters. But exactly the same argument would apply to hon. Members from Scotland or from Wales. ${ }^{14}$

Responding, Rose contrasted his ability to comment on any Scottish issue with the

lack of such a privilege in respect of Northern Ireland, whereas Orr was free to

comment on anything before the House,${ }^{15}$ prompting Orr to stress the same point

made by O’Neill to Wilson:

I accept that argument up to a point. It was clearly understood in the debates on the Government of Ireland Act, 1920. This is the reason why the constituency of my hon. and learned Friend the Member for Antrim, South (Sir Knox Cunningham) is twice the size of the hon. Member's constituency at Blackley. This is why the Act of 1920 limited the number of Members from Northern Ireland, because they could not start limiting their powers and functions.

The people of Northern Ireland are taxpayers. The Budget produced at the Dispatch Box in this House applies to all my constituents. Until recently, for example, it might have been thought wrong for a Member from Northern Ireland to express any view about, let us say, the affairs of London Transport. But London Transport is now to be subsidised in order to keep down the fares of London commuters. My constituents in County Down will have to pay a portion, it may be only a small portion, of that subsidy. Why on earth should they have no say in it? The hon. Member is on a bad constitutional argument and I do not think that it is worth spending too much time on it. ${ }^{16}$

Later, in a speech to fellow Ulster Unionists, Orr accused Labour left-wingers of attempting

to upset the convention by which Northern Ireland matters were not discussed at

Westminster. For Orr, this convention was 'fundamental' to Northern Ireland's constitution,

and his remarks have interest in relation to UK devolution since 1999. He argued as follows:

If Stormont matters are permitted to be discussed at Westminster, a Minister or Ministers at Westminster will have to assume the responsibility for Northern Ireland affairs. No minister will assume such responsibility without the power to go with it. This ultimately means the end of the freedom of action of Stormont which would be reduced to a mere agency of the United Kingdom Government. ${ }^{17}$ 
The rights of Scottish MPs at Westminster also became a matter of debate around the same time as the Wilson Labour government contemplated the Northern Ireland case. In 1967, a row broke out over the attempted exclusion of a Scottish MP, John Mackintosh, from a specialist committee on agriculture, the remit of which did not extend to Scotland, set up by the leader of the House, Richard Crossman. ${ }^{18}$ Mackintosh, a constitutional affairs scholar, was not likely to take this lying down and he responded combatively, citing the Northern Ireland precedent and the related significance of Scotland's 'administrative devolution' arrangements of the time. Mackintosh argued:

It has always been accepted that members are elected to a UK Parliament and that there are no grounds for excluding them from discussions because they represent one constituency or another. This has been stated authoritatively over Northern Irish members when they have taken part on the floor of the House and in Committee not merely on matters solely affecting England but on matters which Parliament cannot discuss in relation to Northern Ireland.

Mackintosh, addressing Crossman, went on:

You cannot suggest a different and harsher rule should apply to Scottish members. It is on this ground among others that English members serve on the Scottish Grand Committee. If there was ever a specialist committee on the Scottish Office, I would oppose it being confined solely to Scots MPs. If this rule was established, it would exclude Scottish members from serving on specialist committees on health, housing and local government, home office affairs, and education as all these have a sub-section in the Scottish Office. Also some of the most useful work comes from comparisons of the experience of very similar problems handled in slightly different ways by the Scottish and the relevant English Department. ${ }^{19}$

For Harold Wilson, the Ulster Unionist MPs’ behaviour remained a sore point, and he was to return to the theme when the civil rights agitation convulsed Northern Ireland in late 1968. Jackson has even speculated that he may have been hinting at a deal over the issue in the context of supporting the O’Neill government through its difficulties. ${ }^{20}$ By this time, Wilson was also facing a Nationalist challenge in Scotland and Wales, to which he responded by setting up a royal commission on the constitution. ${ }^{21}$ Significantly, Northern Ireland was included within the remit of the enquiry, and O'Neill even influenced decisions on the commission's terms of reference. ${ }^{22}$ The commission's deliberations were to have far-reaching consequences as constitutional matters shaped the political and parliamentary agenda of the following decade. 


\section{The Political Significance of Northern Ireland Representation at Westminster, 1972-9}

The prorogation of the Stormont parliament by the Conservative government in March 1972 resulted in the political framework of the Northern Ireland question being significantly redrawn. The subsequent search for a solution focused on the restoration of a form of devolved government for the province that would command sufficient cross-community support. However, in the absence of such a solution being arrived at - the power-sharing executive produced by the Sunningdale agreement of December 1973 was only able to survive five months - the Westminster parliament was the only body in which Northern Ireland's elected representatives could be heard..$^{23}$

For some 50 years, the people of Northern Ireland had become accustomed to paying scant attention to the performance of its small band of MPs at Westminster; indeed, there was a substantial degree of public cynicism about them 'hiding' in London and being out of touch. ${ }^{24}$ Scholarly appraisals of the 'Ulster Party' at Westminster have highlighted the uneasy, and often fractious, relationships between the Westminster Unionist MPs and the governing Ulster Unionist Party (UUP) in Belfast, and the unwillingness of the constituency parties to invest in representatives of a higher calibre. ${ }^{25}$ In the 1960s, when Northern Ireland's government came under pressure over civil rights issues and allegations of discrimination, the Unionists paid the price for the long years of neglect concerning the quality of their representation in London, and the festering of personal jealousies and tensions over influence and position. Notwithstanding some anxieties on the part of the Heath government, the Ulster Unionist MPs mobilised little effective opposition to the imposition of direct rule. ${ }^{26}$

From the time of the suspension of Stormont, it became essential for Unionists to professionalise the Westminster dimension of their operation, and Jackson has observed that the Ulster MPs certainly worked notably harder after $1972 .{ }^{27}$ Back in Ulster, constituency associations paid much more attention to the choice of candidates for Westminster seats. ${ }^{28}$ 
If the removal of Stormont caused consternation among Ulster Unionists in general, there was, nevertheless, a perception on the part of particular Westminster Unionist MPs of an opportunity to enhance their standing. Direct rule, after all, could plausibly be regarded as compatible with unionism's core principles, however much the party's pride in Northern Ireland had been damaged. For those Unionist political voices outside of the old governing party, particularly the Reverend Ian Paisley, the doing-away with the UUP power base was not a matter for despondency; indeed, Paisley was publicly to push the line of integration with the rest of the UK as his preferred political option in 1972-3. At this crucial juncture, unionism and loyalism in fact spoke with a variety of voices and spanned a lengthy spectrum of views on the constitutional question. ${ }^{29}$

For those who were happy to take up the challenge - and the opportunity - of a new role and greater influence at Westminster, there was a clear and urgent objective: Northern Ireland's representation in the house of commons should be increased. Soon the matter of representation occasioned deliberation in Whitehall. In January 1973, as the royal commission on the constitution, chaired by Lord Kilbrandon following the death of Crowther, was bringing its work to a close, a memorandum by Ian Burns of the Northern Ireland Office (NIO) on 'NI Representation at Westminster' referred to the 'strong pressure' for an increase in MPs, and provided comparable figures for the other parts of the UK. Burns noted that Northern Ireland was then represented by $12 \mathrm{MPs} ;{ }^{30}$ the Government of Ireland Act of 1920, which provided for the devolved structures for the six-county unit also reduced Westminster representation, so that in Northern Ireland, a constituency would have an average of 50,738 electors in comparison with an average in Great Britain of 34,158. Burns observed that there was clear logic to the argument that Northern Ireland, on account of the loss of its devolved parliament, should have the same degree of representation at Westminster as other areas of the UK. Even if devolution was restored, Westminster's role in the affairs of the province 
would be likely to remain so crucial as to justify the case for an increase. Burns also noted that, depending on the basis of comparison, Northern Ireland could be said to be entitled to as many seats as 20 , if Scotland was taken as the reference point, or 19 , if the comparison was with Wales, or 16, if it was England. For Great Britain as a whole the entitlement would be 17, while if there was an equal share-out of all 635 seats, then Northern Ireland would have 16 members. $^{31}$

The Conservative government's white paper on 'Northern Ireland Constitutional Proposals' of March $1973^{32}$ outlined the power-sharing and 'Irish Dimension' model that was agreed at the end of the year at Sunningdale, although a majority of the various Unionists returned in the Northern Ireland Assembly elections in June were opposed. In his diary for 23 March, the newspaper baron, Cecil King, records a conversation with Labour MP, Brian Walden, who told him that the proposal in the white paper that the Northern Ireland representation at Westminster should remain at 12 MPs was the condition laid down by the Labour Party for a bipartisan policy on Ireland. King notes that Heath would, nevertheless, face great pressure from his own party and from Northern Ireland to raise the number to $20 .{ }^{33}$ Certainly it seems that the issue assumed great significance for the Labour Party, a reflection probably of the way the voting behaviour of the Ulster MPs had incensed the party hierarchy during the Wilson years in government; the Ulster Unionist refusal to compromise had left a bitter aftertaste. Essentially, the Labour Party had no wish to see Northern Ireland representation strengthened since this would only, in all likelihood, mean more political opponents.

Ulster Unionist MPs at Westminster, such as future UUP leader, James Molyneaux, highlighted the issue of representation around claims of a substantially-increased workload for Ulster MPs since the abolition of Stormont, ${ }^{34}$ and the case for change received a signal boost with the publication of the (Kilbrandon) royal commission report at the end of October. 
This report was primarily notable for its recommendation that elected devolved assemblies should be established for Scotland and Wales, but the report also drew on the Northern Ireland experience of devolution between 1921 and 1972, took evidence from Northern Ireland, and recommended that the province's representation at Westminster now be increased to 17 MPs. ${ }^{35}$ The commission's deliberations had, in fact, caused the government some anxiety when it appeared that interim conclusions reached in 1971 suggested Stormont had actually worked well and that the real difficulties and legitimate criticisms about gerrymandering and discrimination related to local government. The Heath government feared that any 'clean bill of health' for Stormont would only strengthen opposition to the new broader-based devolutionary path he and his secretary of state, Willie Whitelaw, were pursuing; nor did the government wish its policy initiative for Northern Ireland to be complicated by demands for 'old Stormont'-style devolution for Scotland and Wales. ${ }^{36}$ In the event, the final report spared the government from any inconvenient recommendations about the political future of Northern Ireland, and, indeed, included a criticism of Stormont's past failure to protect the interests of the minority that chimed with the thrust of the government's white paper. ${ }^{37}$ None the less, it may have been felt that such reticence to create difficulties for the government should be balanced with the firm recommendation that Northern Ireland's representation at Westminster should be determined by the rules applied to other parts of the UK, given the removal of Stormont. Moreover, the representation issue exercised the fastidious minds of Whitehall and the NIO. On being shown a summary of Kilbrandon's conclusions ahead of publication, D.J. Trevelyan of the NIO forecast 'problems' surrounding the MPs' question: 'We are going to hear a lot more of this from the Unionists, among others. $^{38}$

Indeed, Ulster Unionists applied parliamentary pressure on the issue, citing the Kilbrandon report, ${ }^{39}$ while the Ulster MPs were joined in their demands by some 
Conservatives. In a letter to the press Molyneaux, along with John Biggs-Davison and other tory MPs, welcomed the Kilbrandon recommendations but made the claim that Northern Ireland was entitled to at least 20 seats, and not just the suggested figure of $17 .{ }^{40}$ This was an early indication of 'dissident' Conservative back-bench opinion over Northern Ireland that focused on the anomalies of the 'direct rule' system of government. ${ }^{41}$

The inconclusive general election of February 1974 resulted in the fall of the Conservatives and the return of Labour as a minority government, and, furthermore, dealt a huge blow to the prospects of the fledgling power-sharing executive in Northern Ireland that had sat since January. At this election, 11 out of the 12 Northern Ireland seats returned opponents of the experiment under the banner of the United Ulster Unionist Council (UUUC), a body comprising Unionists from different parties all united in opposition to the concept of power-sharing as of right, and to the 'Irish Dimension' involving the government of the Republic of Ireland. The executive later fell in May 1974 amidst the chaos produced by the Ulster Workers' Council (UWC) strike. In the general election of October 1974, Labour emerged with an overall majority of three seats while Northern Ireland, again, gave a strong endorsement to the hard-line Unionists. In July 1974, during a debate on Kilbrandon, Unionist MP, Robert Bradford, had called for the increase in the province's representation to be taken forward so that the house of commons would 'reflect the will of the majority in Northern Ireland' when sovereignty was claimed by a 'foreign state'. In the same debate, Social Democratic and Labour Party (SDLP) MP and leader, Gerry Fitt, put the Nationalist objection to any increase on the grounds that it would be likely merely to entrench intransigent Unionist views over political change. ${ }^{42}$

On assuming office after the first 1974 election, Labour, again led by Wilson, felt constrained to head off the growing Scottish National Party (SNP) threat - they won seven seats in the February poll and would go on to add four more in October - by pursuing plans 
for devolution. In the white paper 'Democracy and Devolution: Proposals for Scotland and Wales' of September 1974 it was laid down, contrary to Kilbrandon, that Scotland and Wales should retain their existing number of members in the house of commons, ${ }^{43}$ an exercise in political self-protection given the Labour strength in Scotland and Wales, and reassurance to those in the Scottish Labour ranks who had feared devolution for the possible repercussions on Scottish representation and influence at Westminster. ${ }^{44}$

However, in proceeding this way, the government clearly also exposed itself to the contention that there was a glaring anomaly in relation to Northern Ireland that required to be remedied. The new Northern Ireland secretary of state, Merlyn Rees, in the wake of the failure of the Sunningdale project, opted to set up an elected constitutional convention to consider what form of government might have the greatest support across the community, and he hoped to distance the Northern Ireland problem from other UK matters such as devolution for Scotland and Wales. ${ }^{45}$ However, this proved difficult in practice.

For the constitutional convention elections of May 1975, the UUUC produced a manifesto, the first demand of which was 'Full representation in the Parliament of the United Kingdom' which was defined as 21 seats, the same in proportion to population as Scotland. Second, the UUUC demanded a 'democratically elected Parliament with a system of government broadly in line with the provisions to be made for constitutional devolution in the United Kingdom as a whole'. The manifesto went on to reject any 'artificial device' for giving any political party or interest a larger share of representation, influence or power than it was entitled to by virtue of electoral support, and any imposed 'Irish Dimension' ${ }^{46}$

By the time of the government's white paper on devolution in late $1975,{ }^{47}$ much political and civil service ingenuity had been spent ensuring that Northern Ireland would be regarded as a separate case from Scotland and Wales, yet it is plausible to argue that the prospect of arrangements resembling the 'old Stormont' for Scotland and Wales only served 
to reinforce Unionist demands for equal treatment, and thus not to be pushed into accepting singular features such as built-in power-sharing. Moreover, it appears from the intervention of the NIO officials in the devolution working groups that the government was encouraged to be extra cautious in what it proposed for Scotland and Wales for fear of exacerbating the Northern Ireland situation. ${ }^{48}$ In the event the white paper led to the defection of two Scottish Labour MPs, and was to prove the basis for the ill-fated and badly-drafted Scotland and Wales Bill which was terminated by the government's defeat on a guillotine motion in February 1977. Meanwhile, in Northern Ireland, the constitutional convention's majority report, issued in late 1975, simply reflected the UUUC position and gave Rees nothing to work with regarding the prospect of a truly consensus-based government. ${ }^{49}$ The convention was finally wound up in March 1976.

At one point in the summer of 1975, the convention appeared to witness growing agreement across traditional and political divides with much good humour and a genuine desire to prove that politics could trump violence. The common points were resentment over the role of ill-informed English politicians and government officials, and of inadequate arrangements for Northern Ireland business at Westminster, and the belief that 'Ulstermen' knew best how to deal with their problems. ${ }^{50}$ The convention, indeed, did appear to supply evidence of the 'Ulster Nationalism' detected by Merlyn Rees, ${ }^{51}$ and this dismayed the emerging integrationist tendency in Ulster Unionism, now best articulated at Westminster by Enoch Powell. Powell had joined the UUP in 1974 and such was this regarded a major 'coup' for the party that he was effectively parachuted into the seat of South Down for the October election of that year and duly elected. Before he left the Conservatives for the UUP, Powell had identified the cause of Ulster as 'the test of Britain's national will to live' ${ }^{52}$ Where others saw a multinational UK state, Powell imagined an organic and unitary British nation, and he possessed a reverence for the Westminster parliament and for the doctrine of the sovereignty 
of parliament that echoed A.V. Dicey, the legal thinker who had done much to supply the constitutional arguments against Irish home rule back in the late 19th and early 20th centuries. ${ }^{53}$ Powell made it his goal to earn his UUP spurs at Westminster with special reference to the demand for an increase in representation in order to substantiate the integrationist line as the defining one for Unionism. In this he was ably supported by James Molyneaux, whose integrationist instincts and wish to play a 'long political game' had already reoriented the UUP at Westminster around the representation issue, and other objectives such as the restoration of meaningful local government and an end to the 'Orders in Council' system by which Northern Ireland legislation was dealt with at Westminster. The scene was set for a campaign to achieve what both men regarded as the invaluable symbolic goal for Unionism of equal treatment in the 'Mother of Parliaments'. In April 1976, Molyneaux made the 'modest claim' that the party's MPs were 'the most effective force that Ulster has yet fielded'. ${ }^{54}$

Yet it would not prove to be a straightforward political manœuvre to reorient Ulster Unionism as a broad movement that encompassed several political tendencies, preoccupations, and aspirations. Indeed, Powell and Molyneaux's prioritising of integrationist goals at Westminster created tensions with many in the UUP itself back in Northern Ireland, particularly the strong pro-devolutionist leader, Harry West, as well as the main political figures outside it, such as Paisley and William Craig. ${ }^{55}$ Even in Powell's own South Down constituency party there was opposition: Colonel E.H. Brush, an elected member of the constitutional convention, declared in April 1976: 'There is something which MPs must remember, the restoration of devolved government is of infinitely greater importance to us at the grassroots than the increase of Ulster members to 18, that aim is part of our manifesto but it is secondary. ${ }^{56}$ 
Powell and Molyneaux, it might be said, paid lip service to the UUUC demand that devolution be restored to Northern Ireland on the same terms as those proposed for Scotland and Wales. In a conversation with the prime minister in October 1975, Powell was frank about his wish to use the complex devolution controversies over Scotland and Wales as a way of 'playing the Northern Ireland question long'. He referred to the 'leverage of devolution' for his own political purposes provided Northern Ireland should not 'move ahead of devolution in Scotland'. ${ }^{57}$ Powell was clearly gratified by the convention's failure, and urged Ulster Unionists to rejoice in the way their representatives were now 'an integral part' of the house of commons in contrast to the past: 'They are no longer a contingent of half-strangers, who appear from outside to complain, to demonstrate, to protest - or to acquiesce. They are part and parcel of the place, working from within.' He added that the MPs had become 'the living evidence of the reality and permanence of the Union’.58

The UUP leader, Harry West, was angered by the apparent indifference shown to the convention by the integrationists, and many of his public interventions in its aftermath were clearly aimed at trying to restore the political credibility he felt he had lost. This could mean flatly contradicting Powell: 'The position of the tiny Ulster group of members at Westminster is not and cannot be an influential one. If they did become really influential, the establishment would act quickly in some way to take their influence from them. ${ }^{59}$ West's view, much ventilated in the proceedings of the constitutional convention, was that the question was not so much raising the number of MPs, although that would be welcome; rather, it was the reality of the Northern Ireland voice never being adequately heard or listened to at Westminster. Nevertheless, future developments were to throw up circumstances West could not then have envisaged for the Ulster MPs to exercise influence in the way craved by Powell. 
As the debate ensued over the Devolution Bill for Scotland and Wales, brought forward by the government now led by James Callaghan, following Wilson's resignation in March 1976, the question of representation loomed larger. As has been well observed by scholars and commentators, then and since, the dogged determination of the anti-devolution Scottish Labour MP, Tam Dalyell, to keep asking what came to be called, after his constituency, 'The West Lothian Question', caused awkward problems for the government. ${ }^{60}$ The question of whether devolution for one part of the UK ought to prevent the representatives of that region from voting on issues pertaining to other parts recalled the situation that existed for over 50 years when Northern Ireland had its own parliament. Speculation about changes to either the number of representatives from the different parts of the UK - it was suggested that English representation be increased to compensate - or to their voting rights, once again highlighted the anomaly of the Northern Ireland case as it then stood, and the compelling arguments for an increase in the number of MPs to which the province was entitled on the basis of direct comparison with the other parts of the UK. ${ }^{61}$

An NIO memo of October 1976 noted the Northern Ireland aspect to the representation question around devolution, and flagged up the opposition of the SDLP. It also drew attention to a vital consideration of the government in its conduct of policy towards Northern Ireland, namely the use of the issue of the increase as bait to entice Unionists to compromise: 'the possibility of increased representation at Westminster is one of the incentives to the Unionists to agree on a form of devolved government: the government have said repeatedly that the time to look at the question of representation at Westminster is when agreement has been reached on devolved government, and not before'. ${ }^{62}$ A follow-up memorandum referred to the new Northern Ireland secretary of state, Roy Mason, desiring 'magnets' such as the promise of an increase in MPs, to lure the local Ulster politicians into dialogue. ${ }^{63}$ 
The matter also landed at the door of the lord president, Michael Foot, responsible for managing the government's legislative programme. ${ }^{64}$ In a memorandum, Foot acknowledged that the Northern Ireland case had to be considered in the context of any change brought about by the devolution legislation, but stressed that Labour's own party interest would be best served by 'the minimum change from the current relativities between the four countries'. Foot's preferred option was a Speaker's conference to consider the representation issue in the round if devolution came into effect for Scotland and/or Wales. ${ }^{65}$

This stance was soon thrown into disarray as back-bench Labour opposition to change in the level of representation erupted, and Callaghan quickly vetoed the Speaker's conference idea. A significant number of back benchers signalled that they would not support the government's 'guillotine' motion on the Scotland and Wales Bill if a Speaker's conference was conceded, and the government, indeed, mobilised on 1 February 1977 against an amendment by Conservative shadow home secretary, Francis Pym, calling for a Speaker’s conference, and fell back on the old line that Northern Ireland representation would be reviewed if there was political agreement there ${ }^{66}$ Foot, in the house of commons, was forced into defending the government's insistence on maintaining the existing levels of Scottish and Welsh representation while 'stone-walling' on Northern Ireland. ${ }^{67}$ A further confidential memorandum on 'Westminster Representation' noted the support Unionists had from the Conservative front bench and some Labour back benchers, while weighing the problem of SDLP and Dublin opposition and a possible violent response from the Provisional IRA: 'It [the increase] might be construed as a shift in the direction of HMG's policy, and a weakening in the resolve to restore devolved government; in particular it might be portrayed as a move towards integration.' The writer of the memorandum reflected the extent to which the matter had proved politically vexatious at a sensitive juncture regarding the government's programme and devolution in particular: 'The sooner we are off this hook the better.' 68 
As it turned out, the government lost the guillotine measure on 22 February 1977 with 22 Labour MPs voting against, and it was left to accept that it would have to think again on the way forward for devolution. ${ }^{69}$ First, it would have to face a no-confidence vote in the House and in this context it needed to ensure support from whatever quarter it could find it. This led Callaghan to sweeten the Unionists with a promise of a Speaker's conference over the Northern Ireland representation issue, a climbdown from his position prior to the guillotine vote. No formal agreement was reached, but three Unionists, including Powell, abstained in the vote of no-confidence which the government, supported by the Liberals with whom they did reach a deal, won comfortably. ${ }^{70}$ Callaghan then kept his promise of a Speaker's conference, while placating the Liberals with a renewed commitment to devolution, this time in the form of separate bills for Scotland and Wales.

The concession of the Speaker's conference in effect removed any doubt that Northern Ireland representation would be increased; it now remained a matter of how many. Notwithstanding its opposition to the proposal, and the sense of inevitability that now surrounded it, the SDLP was represented at the conference in the form of its leader, Gerry Fitt. Both Molyneaux and Powell served along with pro-integration Conservatives, such as Ian Gow and Philip Goodhart. The conference first met on 27 July 1977, held a total of eight meetings, took oral and written evidence, and finally resolved by 18 votes to four that there should be an increase in the number of parliamentary constituencies in Northern Ireland, and by 22 votes to one that the figure should be $17 .{ }^{71}$ Legislation was eventually pushed through to this effect in 1979.

In his evidence to the conference, Foot asserted that consideration of the question of representation in Northern Ireland should not prejudice subsequent debate affecting the UK as a whole; nor did he think that the conference should take into account the question of Northern Ireland receiving devolved government in the future. In relation to the latter issue, 
Foot, in response to probing by Fitt, said that discussions about devolution looked like being 'blocked altogether' because of the unsatisfactory nature of Northern Ireland representation, a comment that would appear to have related either to his desire to re-state the government's wish for devolution to return to Northern Ireland in an acceptable form, or his frustrations over devolution more broadly, as recently evinced in the Scotland and Wales Bill fiasco. ${ }^{72}$

In its written submission to the conference, the SDLP claimed that there were 'good and fundamental reasons' that Northern Ireland's representation should be viewed differently, and that any decision to change the situation represented 'a major departure from established practice' and, therefore, constituted 'a major political decision about the future of Northern Ireland' ${ }^{73}$ Nationalist anxiety about a possible change in direction by the British government was also a theme taken up in Dublin. The Taoiseach, Jack Lynch, felt obliged to raise the matter in a meeting with Callaghan and Mason at the end of September 1977, and he was glad to receive what he took to be reassurances:

Before I came I was concerned that recent events gave some people at least the impression that there was a move towards integration ... by reason of the Northern Unionists voting with the British government in certain divisions in the House of Commons, by reason of the establishment of the Speaker's Conference the purpose of which is to increase the representation of the Northern Ireland members at Westminster. There was a feeling, then, that all these things might seems to point towards integration rather than devolved government and I was very happy to get the assurance from Mr. Callaghan that it was and remained the policy of the British government to have devolved government with power-sharing and that there would be no devolved government without power-sharing. He was very emphatic in this respect. ${ }^{74}$

Nevertheless, any hopes Lynch might have entertained about progress being made on powersharing were to be frustrated during what remained of the Callaghan government. Mason's main focus was decidedly on economic and security matters, and on representing direct rule in a more positive light. ${ }^{75}$ While in March 1978, Mason is reported as being eager to proceed with the legislation for an increase in Northern Ireland representation, ${ }^{76}$ he informed Callaghan in September of the same year that the prospect of such legislation undermined his work for a 'partnership administration' in the way it alienated Nationalists and brought satisfaction to Unionists. ${ }^{77}$ This might be interpreted as Mason attempting to evade any 
political blame for a lack of progress towards the inter-party dialogue that he clearly felt stood little chance of success at that juncture. His scepticism regarding the launching of political initiatives for their own sake, without a secure enough grounding, was evident enough, and his outlook had much in common with that of Molyneaux and Powell. That said, the suggestion by Molyneaux that both he and Powell believed Callaghan to have been 'mugged' by the Foreign Office and NIO as a 'punishment' for granting the increase in Northern Ireland MPs, seems far-fetched. ${ }^{78}$ What Molyneaux interpreted as the prime minister being warned against any further measures that would alienate Nationalists, would seem, more plausibly, to have been Callaghan's desire to maintain cross-community devolved government for Northern Ireland as the government's policy objective, in spite of the difficulties that the representation matter had caused and regardless of the remote prospects of a settlement actually being reached in the conflict. It made sense for Callaghan to preserve at least the appearance of balance while, for tactical reasons, he kept the Unionists close. Callaghan, according to the accounts of adviser, Bernard Donoughue, was keen for Mason not to be perceived as in the pocket of the Unionists, ${ }^{79}$ equally, in his own memoirs, Callaghan admits that his government had 'never seemed in sight of an agreement' that would have satisfied both sides in Northern Ireland. ${ }^{80}$

Part of the reason why any political breakthrough was highly unlikely concerned, of course, the parliamentary arithmetic at Westminster during the Callaghan government's desperate struggle for survival. To this, the tacit working arrangement that the government reached with the Unionists, primarily through the diplomacy between Foot, Molyneaux and Powell, was crucial. Having secured the verdict of the Speaker's conference, the Unionists then needed to play a patient game to ensure that the relevant legislation would pass. In the light of much Labour opposition, ${ }^{81}$ and pressure exerted by Unionists in Northern Ireland to bring down the government, this was a precarious enterprise. An indication of the care taken 
by Molyneaux not to risk the fulfilment of the goal of the increase was well illustrated by his choice of Wales as the basis of comparison for a change to the number of Northern Ireland MPs: had he chosen Scotland as the benchmark he would have been obliged to argue for 20 or 21 seats rather than the 17 that were ultimately secured. Indeed, several of the Unionist and loyalist bodies that had submitted evidence to the Speaker's conference had strongly urged that the Scottish example be followed. ${ }^{82}$ However, Molyneaux reasoned that Scotland was over-represented, and that in the advent of devolution would be likely to have its representation reduced. He did not want Ulster thrown into 'the same melting pot' if it was to receive devolution. ${ }^{83}$

Molyneaux secured Callaghan's personal intervention over the final passage of the bill to provide the extra seats amidst last-ditch attempts to thwart it in January 1979. The bill was duly given its assent in March. The careful parliamentary game orchestrated by Molyneaux and Powell received its pay-off. The tactical abstentions and occasional support for the government had done much to prolong its life. David Owen, foreign secretary in the Callaghan government, later reflected that the 'informal' Labour-Unionist pact, while less remarked upon than the formal and shorter-lasting 'Lib-Lab' pact, constituted 'a more stable relationship' and was 'at least as important in the survival of the Labour government'. ${ }^{84}$ Nemesis, however, arrived for Callaghan in the vital no-confidence motion in March when Gerry Fitt and Frank Maguire (Independent Nationalist) withdrew support from the government and brought it down, paving the way for the general election of May $1979 .{ }^{85}$

\section{Conclusion}

The question of raising the number of Northern Ireland MPs at Westminster during the 1970s brought together a number of significant political themes. The case for an increase following the removal of the devolved institutions in March 1972 highlighted the way that reduced representation for the province had been viewed as a fair 'trade-off' for devolution between 
the years 1921 and 1972, and thus an important precedent for any future devolution schemes. The issue also drew attention to the broader anomaly of Northern Ireland MPs' voting behaviour in the house of commons during the half-century of devolution, and provided a crucial reference point for the debate occasioned by devolution proposals for Scotland and Wales around what was christened in the mid 1970s, the 'West Lothian Question'.

In its eagerness to undermine Scottish and Welsh Nationalism through commitments to devolution, the Labour government, on its return to office in February 1974, failed to do sufficient ‘joined up’ constitutional thinking. The Wilson government took little heed of the Kilbrandon report's recommendations in relation to pruning Scottish and Welsh representation in the event of devolution, and to increasing Northern Ireland's quota of MPs in the absence of devolution. The provisions in the 'Democracy and Devolution' and 'Our Changing Democracy' papers for Scotland and Wales to maintain the same level of representation, served to sharpen the political demands for a Northern Ireland increase, and invited a critical onslaught around Labour's apparent prioritising of its own party interest ahead of constitutional equity and fair dealing. ${ }^{86}$

The Callaghan Labour government also exposed itself to the charge of using the matter in a nakedly instrumentalist fashion, first seeking to keep the promise of an increase as a bargaining chip to soften Unionist opposition to co-operation with the SDLP, then making the considerable concession of a Speaker's conference on the Northern Ireland representation issue alone in order to form a working relationship with Unionists at Westminster. The government tried to keep its Northern Ireland policy options open for as long as it could, but its hand was forced by the loss of the guillotine motion over the Scotland and Wales Bill in February 1977. This episode demonstrated that attempts to compartmentalise the Northern Ireland problem and devolution for other parts of the UK were always liable to be frustrated. Indeed, Merlyn Rees, as Northern Ireland secretary, had been confronted by a heightened 
Unionist desire to be made part of the apparent constitutional restructuring of the UK promised by the Labour government, and this, arguably, fed into the UUUC's reluctance to concede any political ground to the SDLP at the constitutional convention. In short, the Northern Ireland question became deeply entangled in the political and parliamentary wrangling over devolution, representation, and constitutional change in general. Yet, rather puzzlingly, the Northern Ireland dimension to the fierce debates about the UK as a 'union' or 'unitary' state in the 1970 s has been routinely neglected. ${ }^{87}$

The eventual passage of the legislation increasing Northern Ireland representation to 17 was a substantial accomplishment for Ulster Unionism at Westminster, in particular the careful campaign plotted by Molyneaux and Powell. Yet the way the latter prioritised the matter and allowed it to be seen as emblematic of an integrationist strategy served to widen rifts among Unionists back in Northern Ireland. Indeed, Powell's prominence seemed to antagonise the strand of Unionism that evinced scepticism about the likelihood of Ulster's interests being advanced at Westminster, and put little store by government guarantees and assurances. Equally, Powell and Molyneaux did not appreciate that their success in relation to the representation issue was not likely to be the precursor of further Unionist gains of an integrationist nature given the government's need to preserve at least the appearance of evenhandedness and a commitment, however compromised in practice by their parliamentary difficulties, to a power-sharing solution. The government had always to be careful to manage relations with Dublin carefully if it was to achieve its objectives regarding security and the quelling of IRA violence.

Nationalist patience in Ireland, north and south, was sorely tested by the Northern Ireland representation saga, and there was much frustration about the prospects of peace being jeopardised for the government's short-term gain. Nevertheless, some Nationalist and Republican reaction betrayed an inability to appreciate the political context in which the 
government found itself, or the way that the issue had become entangled with wider UK constitutional questions since at least the time of the publication of the Kilbrandon report. Seán MacBride, a veteran Irish Republican who had acquired an international reputation for human rights causes by the 1970s, was quoted as saying of the decision to increase representation that it was 'a far more damaging assertion of Britain's intention to continue to assert her sovereignty in the six counties than anything that has happened so far'. 'It is a provocative indication', MacBride went on, 'that Britain will continue to exercise her domination over the northeastern part of Ireland. ${ }^{, 88}$

This was a measure of how far Irish Republicans and even some moderate Nationalists continued to frame the Irish question in terms of an assumed British 'imperialist' mindset that other evidence, whether political diaries and memoirs or government records of the day, overwhelmingly refutes. Clearly, the symbolic significance of the increase in Northern Ireland representation should not be underestimated in relation to the depth of division between Unionists and Nationalists at this juncture over the nature of the conflict and how to make progress towards peace. Equally, there is little that might be drawn from the political saga surrounding the issue to suggest that the Labour government desired the closer integration of Northern Ireland, and it was certainly regretful about the impact the controversy had on its relations with the SDLP. It was, rather, a complication among many others during an exceptionally precarious tenure of office, and a matter that could not be prevented from spilling out into other realms of policy.

\footnotetext{
${ }^{1}$ G. Walker, A History of the Ulster Unionist Party: Protest, Pragmatism and Pessimism (Manchester, 2004), 77.

${ }^{2}$ A. Jackson, ““Tame Tory Hacks”? The Ulster Party at Westminster, 1922-1972’, Historical Journal, liv (2011), 453-75.
} 
${ }^{3}$ The 'West Lothian' tag derived from the constituency of Tam Dalyell, the Scottish Labour MP who made the voting anomaly a central part of his critique of devolution. For the McKay Commission see Report of the Commission on the Consequences of Devolution for the House of Commons, March 2013 (published at tmc.independent.gov.uk) ; and commentary in I. McLean, 'Reports and Surveys’, Political Quarterly, lxxxiv (2013), 395-8.

${ }^{4}$ D. Sandbrook, White Heat (2006), 98.

${ }^{5}$ TNA, HO 221/50: Professor Thomas Wilson, memorandum: 'Regional Government (with special reference to Northern Ireland)' (Nov. 1969), in 'Royal Commission on the Constitution - Written Evidence (6) Northern Ireland', 74.

${ }^{6}$ See relevant documents regarding Wilson's intervention, in TNA, PREM 13/1663; also, Walker, Ulster Unionist Party, 155-6.

${ }^{7}$ TNA, PREM 13/1663: note of meeting between Wilson and O’Neill, 19 May 1965; see also K. Theakston, 'Prime Ministers and the Constitution’, Parliamentary Affairs, lviii (2005), 17-37.

${ }^{8}$ Hansard, Commons Debates, 5th ser., dccxviii, cols 96-7: 26 Oct. 1965, cited in P. Bowers, 'The West Lothian Question’, House of Commons Library Standard Note (SN/PC/2586), 18 Jan. 2012.

${ }^{9}$ P. Bew et al., Northern Ireland: 1921-2001 (2001), 126-32.

${ }^{10}$ G. Walker, 'Scotland, Northern Ireland and Devolution, 1945 - 79', Journal of British Studies, xlix (2010), $117-42$.

${ }^{11}$ TNA, HO 221/113: G.B. Adams, memorandum (Feb. 1970), in 'Royal Commission on the Constitution Written Evidence (6) Northern Ireland', 16.

${ }^{12}$ Adams, memorandum, 19.

${ }^{13}$ Hansard, Commons Debates, 5th ser., dccxviii, col. 73: 26 Oct. 1965.

${ }^{14}$ Hansard, Commons Debates, 5th ser., dccxviii, col. 80: 26 Oct. 1965.

${ }^{15}$ Hansard, Commons Debates, 5th ser., dccxviii, col. 81: 26 Oct. 1965.

${ }^{16}$ Hansard, Commons Debates, 5th ser., dccxviii, col. 81: 26 Oct. 1965.

${ }^{17}$ Public Record Office of Northern Ireland [hereafter cited as PRONI], D1327/20/1/31: Ulster Unionist Council yearbook, 1967.

${ }^{18}$ See The Crossman Diaries, abridged version, ed. Anthony Howard (1979), 312-3.

${ }^{19}$ National Library of Scotland (NLS), Mackintosh Papers, Dep 323/95: Mackintosh to Crossman, 31 Jan. 1967.

${ }^{20}$ Jackson, ““Tame Tory Hacks”?’, 469. 
${ }^{21}$ Royal Commission on the Constitution, 1968-73, Cmnd 5460 (HMSO, 1973) [hereafter cited as Kilbrandon].

${ }^{22}$ Walker, 'Scotland', 129-30.

${ }^{23}$ It should also be kept in mind that significant local government functions were taken away, from 1970, and given to unelected bodies. On local government reform, see P. Arthur, Government and Politics of Northern Ireland (Harlow, 1980), 96-8.

${ }^{24}$ See A. Purdy, Molyneaux: The Long View (Antrim, 1989), 95-6.

${ }^{25}$ Jackson, ““Tame Tory Hacks”?’, 457; Walker, Ulster Unionist Party, 106, 122-3, 155-6.

${ }^{26}$ See Walker, Ulster Unionist Party, 196; Jackson, ““Tame Tory Hacks”?’, 472.

${ }^{27}$ Jackson, ““Tame Tory Hacks”?’, 459.

${ }^{28}$ Walker, Ulster Unionist Party, 218.

${ }^{29}$ Walker, Ulster Unionist Party, ch. 6.

${ }^{30}$ Initially it was 13, but the university seat was abolished in 1948.

${ }^{31}$ TNA, CJ4/545: Burns memorandum, 3 Jan. 1973.

${ }^{32}$ Northern Ireland Constitutional Proposals, Cmnd. 5259 (HMSO, 1973).

${ }^{33}$ The Cecil King Diary 1970-1974 (1975), 276; see also TNA, CJ4/517: note of meeting between the secretary of state (William Whitelaw) and UUP deputation, 12 Dec. 1972, at which Whitelaw admitted that the Conservative Party favoured an increase.

${ }^{34}$ Purdy, Molyneaux, 96.

${ }^{35}$ Kilbrandon, para. 1338; see also TNA, CJ4/517: note of meeting between Frank Cooper (NIO) and UUP leader, Brian Faulkner, 25 Oct. 1973, at which Faulkner said that any suggestion in the report of an increase would be 'a great prize'.

${ }^{36}$ Walker, 'Scotland', 130. The government had actually considered delaying the publication of Kilbrandon to ease potential difficulties in this regard, but eventually consented to publication in Oct. 1973.

${ }^{37}$ Kilbrandon, para. 214.

${ }^{38}$ TNA, CJ4/338: Trevelyan to Miss Overy (home office), 11 July 1973.

${ }^{39}$ Hansard, Commons Debates, 5th ser., dccclxiii, col. 121: 6 Nov. 1973: written question by Stratton Mills.

Heath's response was that the Northern Ireland representation issue could not be considered separately from devolution to Scotland and Wales.

${ }^{40}$ Daily Telegraph, 16 Nov. 1973.

${ }^{41}$ For discussion, see M. Cunningham, 'Conservative Dissidents and the Irish Question: The Pro-Integrationist Lobby 1973-94’, Irish Political Studies, x (1995), 26-42.

${ }^{42}$ Hansard, Commons Debates, 5th ser., dccclxxviii, col. 264: 29 July 1974; for Fitt contribution, cols 297-301.

${ }^{43}$ Democracy and Devolution: Proposals for Scotland and Wales, Cmnd 5732 (HMSO, 1974), paras 32, 33. 
${ }^{44}$ See TNA, CJ1/89: memorandum dated 14 Dec. 1949. This had been the argument used against devolution by such figures as Scottish secretary of state, Arthur Woodburn, in the late 1940s, and it underpinned the Scottish party's stance on the matter from 1958 through to 1974. See also evidence given to the royal commission by John P. Mackintosh, reproduced in John P. Mackintosh on Scotland, ed. H. Drucker (1982), 61-81.

45 See M. Kerr, The Destructors (Dublin, 2010), 268, and 322-3 for Rees’s opposition to the increase in MPs; see also B. Donoughue, Downing Street Diary (2 vols, 2006-8), i, 285, for Rees and his anxiety about Scottish devolution complicating his work on Northern Ireland.

${ }^{46}$ Manifesto reproduced in R. Rose, Northern Ireland: A Time of Choice (Washington, DC, 1976 ), 81 ; see also H. Patterson and E. Kaufmann, Unionism and Orangeism in Northern Ireland since 1945 (Manchester, 2007), 166, for policy statement of Apr. 1974.

${ }^{47}$ Our Changing Democracy: Devolution to Scotland and Wales, Cmnd 6348.

${ }^{48}$ Walker, 'Scotland', 135-6.

${ }^{49}$ In Oct. 1975, the leader of the Vanguard Unionist Party, William Craig, long regarded as one of the most extreme opponents of compromise, signalled his willingness to enter a voluntary coalition with the SDLP, but he could not carry sufficient Unionist support.

${ }^{50}$ See, e.g., Northern Ireland Constitutional Convention, Report of Debates (Belfast, 1975), 234, 239, $268,282$.

${ }^{51}$ M. Rees, Northern Ireland: A Personal Perspective (1985), 21, 91-2, 202-3; also Kerr, Destructors, 298. The foreign and commonwealth office (FCO) certainly gave consideration to the idea of negotiated independence: see TNA, FCO 87/440: memorandum dated 28 Aug. 1975.

${ }^{52}$ P. Cothorn, 'Enoch Powell, Ulster Unionism, and the British Nation', Journal of British Studies, li (2012), 967-97.

53 See D.G. Boyce, 'Dicey, Kilbrandon and Devolution', Political Quarterly, xlvi (1975), 280-92; J. Mitchell, Devolution in the UK (Manchester, 2009), 222-5.

${ }^{54}$ PRONI, Ulster Unionist Council (UUC) Papers, D1327/21/40: Molyneaux speech dated 2 Apr. 1976.

${ }^{55}$ For detailed treatments of late 1970s Unionist politics, see Patterson and Kaufmann, Unionism, ch. 5; and Walker, Ulster Unionist Party, ch. 6.

${ }^{56}$ PRONI, D1327/21/40: Brush speech dated 27 Apr. 1976. Strictly speaking Brush was mistaken if the manifesto is taken to be the UUUC one for the convention elections, but his assessment of grassroots feeling may well have been accurate.

57 TNA, CJ4/784: 'Call on the PM', 30 Oct. 1975.

58 PRONI, D1327/21/40: Powell speech dated 22 Apr. 1976.

${ }^{59}$ PRONI, D1327/21/40: West speech dated 14 May 1976.

60 See, e.g., V. Bogdanor, Devolution (Oxford, 1979), 161; Mitchell, Devolution, 202-3; A. Marr, The Battle for Scotland (1992), 157-8.

${ }^{61}$ See house of commons debate on Scotland and Wales Bill: Hansard, Commons Debates, 5th ser., cmxxv, cols 261-2, 358, 418 (Powell), cols 377-8 (Pym), col. 393 (Kilfedder): 1 Feb. 1977.

62 TNA, CJ4/1852: memorandum by JDN James, 5 Oct. 1976.

63 TNA, CJ4/1852: memorandum by JM Stewart, 28 Oct. 1976; see also Mason, in Hansard, Commons Debates, 5th ser., cmxxi, col. 1143: 2 Dec. 1976. When Whitelaw was secretary of state he had also considered using the issue as a 'carrot' to Unionists to moderate their stance: see Kerr, Destructors, 64; and TNA, CJ4/517 (see above, note 32). 
${ }^{64}$ For an account of Foot's management of the devolution issue, see K.O. Morgan, Michael Foot (2008), 351-9.

65 TNA, CJ4/1852: memorandum by Foot on 'Scottish and Welsh Representation in the House of Commons', nd; see also TNA, CAB 128/61: 20 Jan. 1977.

66 TNA, CJ4/1853: memorandum by JB Bourn, 1 Feb. 1977.

67 TNA, CJ4/1853: memorandum by D. Chesterton, 9 Feb. 1977; see also Hansard, Commons Debates, 5th ser., cmxxv, cols 393-5: 1 Feb. 1977; and Powell's claim in this debate that Foot did not believe in the case he was making (col. 413) and his statement that the Northern Ireland representation issue was 'upon the conscience of the House and it will not go away until it is dealt with' (col. 418).

68 TNA, CJ4/1853: memorandum, nd.

69 TNA, CAB 128/61: 24 Feb. 1977. Concerns were expressed about the ‘English dimension’ and the risks of the referendum option.

${ }^{70}$ See accounts in Purdy, Molyneaux, 101-9; J. Callaghan, Time and Chance (1988), 453-5. See also Hansard, Commons Debates, 5th ser., cmxxviii, cols 1302-4: 23 March 1977, for Callaghan's remarks on dealings with the Unionists.

${ }^{71}$ Conference on Electoral Law, Cmnd 7110 (1978).

${ }^{72}$ House of Commons Paper 70-ii, Mr. Speaker’s Conference on Electoral Law, Minutes of Evidence, 30 Nov. 1977 (HMSO, 1977).

${ }^{73}$ House of Commons Paper 70-iii, Mr. Speaker's Conference on Electoral Law, Papers submitted to Conference July-Dec. 1977 (HMSO, 1978).

${ }^{74}$ Boston College Burns Library [hereafter cited as BCBL], T.P. O’Neill Papers, box 24/3: note of meeting, 28 Sept. 1977. See Callaghan's account in Time and Chance, 499 - the British government's main concern was security.

${ }^{75}$ PRONI, FIN 30/R/1/1: file on ‘Administrative Devolution’; see undated memorandum accompanied by a note dated 19 Jan. 1977.

${ }^{76}$ Donoughue, Downing Street Diary, i, 299.

${ }^{77}$ PRONI, CENT/1/7/24: memorandum dated 13 Sept. 1978.

${ }^{78}$ Purdy, Molyneaux, 104-5.

${ }^{79}$ Donoughue, Downing Street Diary, i, 299, 334-5.

${ }^{80}$ Callaghan, Time and Chance, 500.

${ }^{81}$ See, e.g., T. Benn, Conflicts of Interest: Diaries 1977-80 (1990), 439; Donoughue, Downing Street Diary, ii, 314.

${ }^{82}$ See House of Commons Paper, 70-iii (note 73 above), submissions by Democratic Unionist Party, Vanguard, Loyal Orange Institution of Scotland, and Unionist Party of Northern Ireland.

${ }^{83}$ Purdy, Molyneaux, 105.

${ }^{84}$ D. Owen, Time to Declare: Second Innings (2009), 190.

85 The government lost by a single vote margin; two Ulster Unionists supported the government. 
${ }^{86}$ See M. Taylor, 'Labour and the Constitution’, in Labour's First Century, ed. D. Tanner et al. (Cambridge, 2000).

${ }^{87}$ For a good summary of the ‘union' and unitary’ state concepts, see I. McLean and A. McMillan, State of the Union (Oxford, 2005), ch. 1. The same book also exemplifies the tendency to 'hive off' Northern Ireland from discussion of political developments around devolution in the 1970s (see chs. 7-9), although not in relation to devolution finance (ch. 10).

${ }^{88}$ Quoted in BCBL, box 21/19: Congressional Record of 6 Mar. 1979. 